極低温流体中でインデューサに発生する旋回キャビテーションの挙動

\title{
Behavior of Rotating Cavitation in a Cavitating Inducer in Cryogenic Fluid
}

○学 笹尾好史 (JAXA 技術研修生)、風見佑介 (JAXA 技術研修生)、正 吉田義樹 (JAXA)

正 井小萩利明 (東北大学流体研)、正 伊賀由佳 (東北大学流体研)

Yoshihumīi SASAO*, Yusuke KAZAMI*, Yoshiki YOSHIDA** Toshiaki IKOHAGI $^{* * *}$, Yuka IGA ${ }^{* * *}$

*JAXA Research Student at Tohoku University, 2-1-1 Katahira, Aoba-ku, Sendai, Miyagi 980-8577

**Japan Aerospace Exploration Agency (JAXA), 1 Koganezawa, Kimigaya, Kakuda, Miyagi 981-1525

***Institute of Fluid Science (IFS), Tohoku University, 2-1-1 Katahira, Aoba-ku, Sendai, Miyagi 980-8577

\section{Key Words: Rotating Cavitation, Thermodynamic Effect, Inducer, cavity length}

\section{1. 緒言}

ロケットエンジン用ターボポンプには吸い込み性能を 向上させるために、メインインペラの上流部にインデュー サが取り付けられている。しかしインデューサには旋回キ ヤビテーション、キャビテーションサージ等のキャビテー ション不安定現象が発生し、旋回キャビテーションは軸振 動や性能低下の原因となる。

本研究ではロケットエンジン用インデューサを用いて 実験を行い、キャビテーション不安定現象の一種である同 期、超同期旋回キャビテーションに着目して、その挙動を 調べた。また温度の異なる液体窒素 $(74 \mathrm{~K} 、 83 \mathrm{~K})$ を作動流体 として用いることにより、熱力学的効果が旋回キャビテー ションに与える影響についても検討した。

\section{1 実験設備}

\section{2. 実験設備と実験装置}

本実験は角田宇宙センターにある極低温インデューサ 試験設備にて行い、作動流体は液体窒素を用いて行った。 インデューサは 3 枚翼でソリディティは約 2.1 である。試 験回転数 $\mathrm{N}=18300 \mathrm{rpm}$ 、流量比 $\mathrm{Q} / \mathrm{Q}_{\mathrm{d}}=1.06$ ( $\mathrm{Q}_{\mathrm{d}}$ : 設計流量) を一定に保ち、入口圧を高い状態から減压するキャビテー ション試験を行った。また液体窒素の温度変化による差異 を調べるために、降温(74K)と昇温(83K)をした液体窒素を 用いる 2 種の実験を行った。

\section{2 実験装置}

非定常キャビテーションの挙動を調べるにはキャビテ ーションを直接観察できることが望ましいが、極低温流体 を用いた試験においてインデューサ内部のキャビテーシ ヨンを可視化することは難しい。そこで、内部の様子を推 定するために図1のようにインデューサのケーシング壁面 に翼に沿ってPos.1(入口側)～Pos.8(出口側)まで 8 個の変動 圧センサを設けた。各位置で翼がセンサ上を通過する時に 発生する圧力変動から、間接的にインデューサの各翼間流 路に発生するキャビテーション発生領域を推定すること により、キャビティ長さ(Lc)を求めた(1)。
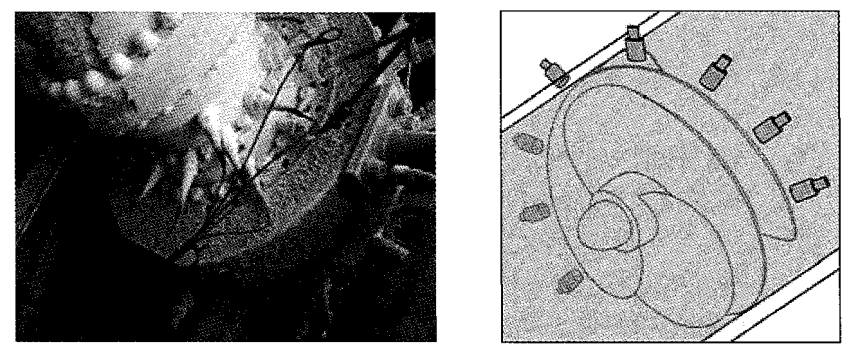

Fig.1 Photograph and illustration around the inducer

\section{3. 実験結果}

図 2 に液温 $74 \mathrm{~K}$ と $83 \mathrm{~K}$ での吸込み性能 $(\sigma-\psi)$ 、キャビテ イ長さ $(\mathrm{Lc} / \mathrm{h}, \mathrm{h}:$ 翼列のスペーシング $)$ と旋回キャビテーショ ンを静止系から見た周波数 $(\omega / \Omega, \omega$ :旋回周波数, $\Omega$ : 軸回転 周波数)を示し、図 3 には $74 \mathrm{~K}$ の同期旋回キャビテーショ ンと、83Kの超同期旋回キャビテーションのキャビティ長 さの代表的な挙動を示す。また図 4 には図 3 中(1)(2)(3)で 示す時間でのキャビティの不均一状態を示す。実験開始後、 キャビテーション数 $\sigma / \sigma_{0} \fallingdotseq 0.8$ 付近になると両実験条件 で、軸回転周波数 $(\Omega)$ より高い周波数 $(\omega / \Omega=1.1 \sim 1.2)$ で旋 回する超同期旋回キャビテーションの発生が確認された。 $\sigma / \sigma_{0} \fallingdotseq 0.8$ よりキャビテーション数の大きなところでは、 3 つの流路のキャビティ長さに不均一性はなかったが、超 同期旋回キャビテーション発生時には、キャビティ長さが 不均一となり 3 流路を回転方向(channel1-2-3-1…)に移りか わることが図 3(A)および図 4(A)から確認できた。この様相 および旋回周波数 $(\omega / \Omega)$ は Iga ${ }^{(2)}$ のCFD の結果と類似し ている。また、超同期旋回キャビテーションの旋回周波数 はキャビテーション数の減少に伴いしだいに低下してい くが、この時インデューサ揚程は変化していない。また図 は省略するが、83Kの場合の超同期旋回キャビテーション は74Kの場合とほぼ同様な挙動を示していた。

その後キャビテーション数 $\sigma / \sigma_{0} \fallingdotseq 0.5$ 付近になると、静 止系から見て軸回転周波数之同じ周波数 $(\omega / \Omega=1)$ で旋回 する、同期旋回キャビテーションが発生した。この時のキ ヤビティ長さを図 3(B)でみると、50 回転中数回だけキャ ビティ長さが変化しているが、キャビティ長さは図 4(B) に示すように不均一性を保ったままほぼ一定の状態とな っているが確認される。また、74Kの場合には同期旋回キ ヤビテーション発生時に揚程が一度低下しているが、83K の実験では74K と異なり揚程は低下していない。またキャ ビティ長さの不均一性を調べると $74 \mathrm{~K} は 83 \mathrm{~K}$ の時に比べ 3 流路における不均一性が大きい。

\section{4. 考察}

キャビテーションでは、キャビティ気泡の成長に必要な 気化熱のために周囲の流体から熱移動が起き、それに伴い キャビティ周囲の温度および飽和蒸気圧が低下し、その結 果キャビティの成長が抑制される。これをキャビテーショ ンの熱力学的効果という。極低温流体の場合はその物性か ら熱力学的効果が顕著に現れる。

4. 1 超同期旋回キャビテーション

図 3 より超同期旋回キャビテーション発生時のキャビテ イ長さの変動振幅は $74 \mathrm{~K}, 83 \mathrm{~K}$ の両条件においてほぼ等し い。このことより熱力学的効果は超同期旋回キャビテーシ 


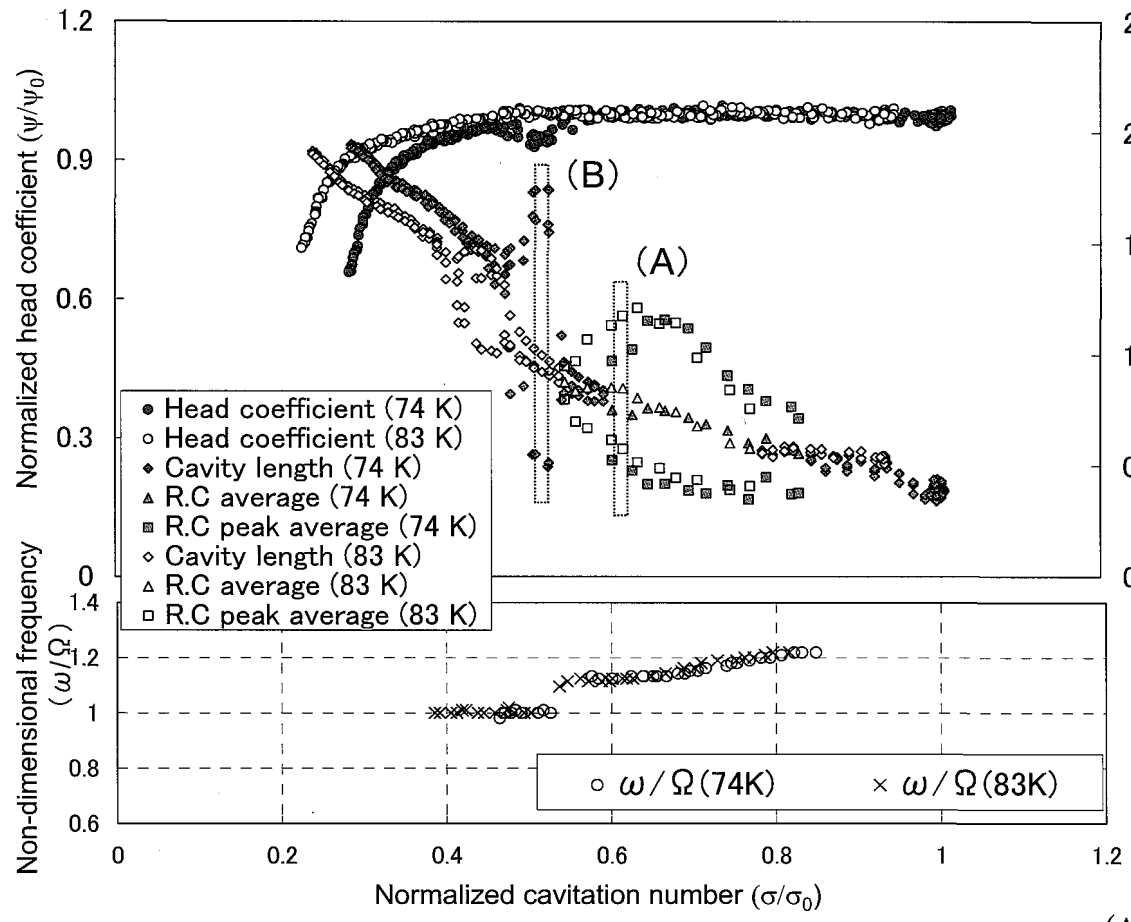

2.5

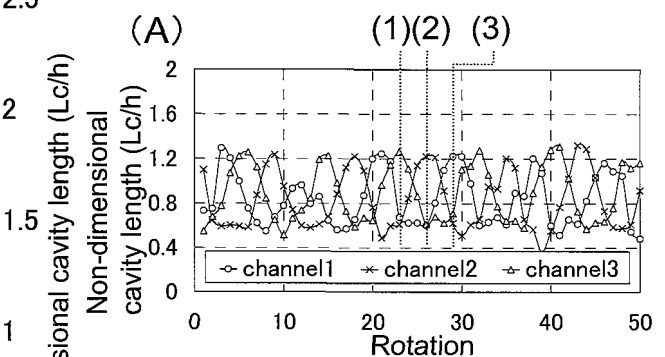

(B) (1)

(2)

(3)

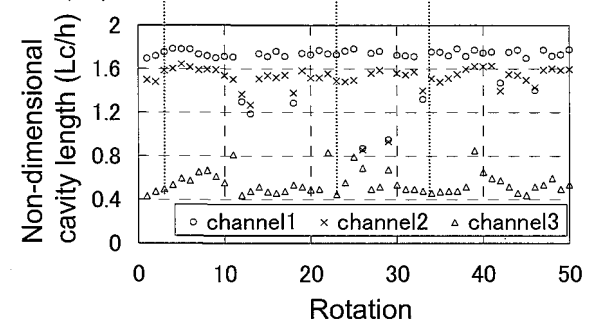

Fig.3 Behavior of cavity length of

Fig.2 Cavity length $(\mathrm{Lc} / \mathrm{h})$, suction performance, and frequency $(\omega / \Omega)$

(A)Super-R.C(83K), (B)Synchronous-R.C(74K)

(1)

(A)

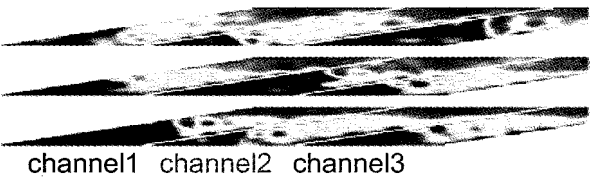

(B)

(1)

(2)

(3)

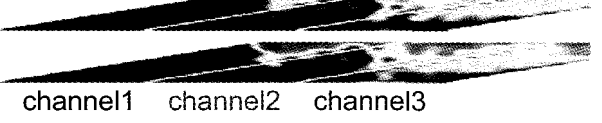

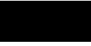

(Estimated cavity region)

Fig.4 Estimated cavity region of (A)Super-R.C(83K), (B)Synchronous-R.C(74K)

ヨン発生中のキャビティ長さの不均一性にさほど影響を 与えていないことがわかる。また超同期旋回キャビテーシ ヨンが発生し始めるキャビテーション数ではキャビティ 長さはいずれも $\mathrm{Lc} / \mathrm{h} \fallingdotseq 0.5$ であるが、 $83 \mathrm{~K}$ の場合には $74 \mathrm{~K}$ の場合に比べてキャビテーション数が小さいほうにシフ 卜している。これは熱力学的効果がキャビテーション不安 定に対してダンピング効果を与えるためと考えている。し かし旋回キャビテーションの旋回周波数は両温度ではほ ぼ同一であり、周波数には熱力学的効果は現れていない。 4. 2 同期旋回キャビテーション

図 2 より $83 \mathrm{~K}$ の場合の同期旋回キャビテーション発生時 のキャビティ長さの不均一性は、74K の場合に比べて小さ くなっている。つまり昇温することにより、熱力学的効果 が大きくなり同期旋回キャビテーション発生中の長いキ ヤビティの成長を抑制し、その不均一性を小さくしている ものと推定される。同期旋回キャビテーションの発生し始 めるキャビティ長さは、 $\omega / \Omega=1$ が明確となる周波数から判 断すると $74 \mathrm{~K} 、 83 \mathrm{~K}$ のいずれの場合もキャビティ長さが $\mathrm{Lc} / \mathrm{h} \fallingdotseq 0.8$ であり (3)その発生点はキャビティ長さに依存し ているといえる。83K の場合は熱力学的効果によって、キ ヤビティの成長が抑制されるために、発生点は74Kに比べ てキャビテーション数の小さい方向にシフトしている。

4. 3 揚程とキャビティ長さ

$74 \mathrm{~K}$ の同期旋回キャビテーション発生中の場合にだけ 揚程低下がみられた。この時、翼間のキャビティ長さはそ れぞれ異なり、もっとも成長したキャビティは Lc/h>1.5 と なっておりその流路がキャビテーションで閉塞されるこ とにより、一時的な揚程低下が発生したものと考えられる。 また低キャビテーション数ではキャビティ長さに不均一 性がなくても $\mathrm{Lc} / \mathrm{h} \fallingdotseq 1.5$ となるあたりから揚程が急激に下
がり始めている。また両試験条件の揚程とキャビティ長さ を比べてみると、キャビティ長さが同じなら揚程低下量も $\mathrm{Lc} / \mathrm{h}>1.5$ でほぼ同じとなることがわかる。つまり揚程低下 はキャビティ長さにのみに依存している。

\section{5. 結言}

液体窒素温度を変化させ、旋回キャビテーションに着目 して考察を進めた結果、以下のような知見を得た。

(1) 旋回キャビテーションの発生点は液体の温度が高い と、熱力学的効果によってキャビテーション数の小さ い方にシフトする。

(2) 超同期旋回キャビテーション発生中のキャビティの 平均長さ、および旋回周波数には熱力学的効果は小さ かった。

（3）低キャビテーション数で発生する同期旋回キャビテ ーション発生中のキャビティ長さの不均一性には熱 力学的効果が現れ、液体温度が高いほどキャビティの 不均一性の程度は小さい。

\section{謝辞}

本研究を進めるにあたり JAXA 角田宇宙センターのタ 一ボポンプセクションの方々に実験データを使用させて いただき、助言していただいたことを感謝いたします。

\section{参考文献}

(1) 吉田義樹・他 5 名,日本機械学会論文集(B 編) 72 巻 713 号(2006-1), pp. 54-60.

(2) Iga, Y - 他 3 名, 2004, ASME Journal of Fluids Engin eering, 126, pp. 419-429.

(3) 吉田義樹 -他 5 名,日本機械学会論文集(B 編) 73 巻 727 号(2007-2) 掲載予定 